\title{
Isolation and identification of anti-methicillin resistant Staphylococcus aureus compounds from Phyllanthus columnaris stem bark
}

\author{
Siti-Noor-Adnalizawati Adnan ${ }^{1 *}$, Nazlina Ibrahim ${ }^{1}$ and Wan Ahmad Yaacob ${ }^{2}$ \\ ${ }^{1}$ School of Biosciences and Biotechnology, Faculty of Science and Technology, \\ Universiti Kebangsaan Malaysia, Bangi, 43600 Selangor, Malaysia. \\ ${ }^{2}$ School of Chemical Sciences and Food Technology, Faculty of Science and Technology, Universiti Kebangsaan \\ Malaysia, Bangi, 43600 Selangor, Malaysia. \\ E-mail: nazlina@ukm.edu.my
}

Received 8 February 2014; Received in revised form 27 May 2014; Accepted 3 June 2014

\begin{abstract}
Aim: Phyllanthus columnaris Müll.Arg. was found to possess anti-methicillin resistant Staphylococcus aureus (antiMRSA) activities. This study aimed at isolating, identifying and evaluating the active compounds from the stem bark of Phyllanthus columnaris Müll.Arg. against MRSA.

Methodology and results: Stem bark extracts (methanol, acetone and aqueous) of Phyllanthus columnaris were subjected to anti-MRSA screening by disc diffusion method. MIC and MBC tests were carried out to compare the lowest concentration to inhibit and kill the sixteen MRSA tested among the three extracts. TLC bioautography were performed to detect the bioactive compounds. Isolation of the two active compounds was performed by means of preparative TLC. Morphological and ultra-structure alterations of the MRSA treated with bioactive compounds after $24 \mathrm{~h}$ were revealed by scanning and transmission electron microscopy. Both methanol and acetone extracts exhibited good anti-MRSA activity with the lowest minimum inhibitory concentration (MIC) value for both extracts were $0.78 \mathrm{mg} / \mathrm{mL}$ and the lowest minimum bactericidal concentration (MBC) were $1.56 \mathrm{mg} / \mathrm{mL}$. Bioassay-guided chromatography by bioautography revealed two active anti-MRSA compounds from both tannin-free methanol and acetone extracts and characterized as stigmasterol and lupeol by nuclear magnetic resonance (NMR) spectral data. Scanning and transmission electron microscopy of MRSA treated with stigmasterol and lupeol showed cell wall disruption, release of cytoplasmic compounds and decreased in cellular volume.

Conclusion, significance and impact of study: Results obtained herein, may suggest that the stem bark of Phyllanthus columnaris possess anti-MRSA and the two of the active compounds isolated were stigmasterol and lupeol. Their anti-MRSA effects up to the morphological and ultra-structure studies were not reported earlier.
\end{abstract}

Keywords: Phyllanthus columnaris, anti-MRSA activity, TLC bioautography, SEM, TEM

\section{INTRODUCTION}

Methicillin resistant Staphylococcus aureus (MRSA) is commonly responsible for both hospital- and communityacquired infections (Hiramatsu et al., 2002; Gastmeier, 2010). MRSA can cause various spectra of clinical diseases ranging from benign superficial skin infections to severe life-threatening conditions such as bacteraemia, endocarditis, pneumonia, abscesses, and soft or bonetissue infections (Falcone et al., 2009). These pathogenic Gram-positive bacteria have become a major threat to health worldwide due to its high prevalence, emergence of virulent strains and resistance to almost all available antibiotics thus increasing in mortality rate (Witte, 1999; Madani, 2002; Kerttula et al., 2007; Delaney et al., 2008). MRSA infection cases in hospitals are rising worldwide due to the decrease in the susceptibility of MRSA to the antibiotics vancomycin and teicoplanin (Vaudaux et al., 2001; Neoh et al., 2007; Weigel et al., 2007).

The emergence of resistant MRSA has led to the search for new sources of anti-MRSA drugs. Fazari et al. (2011) showed that methanol extracts from different parts of Phyllanthus columnaris displayed antibacterial activity against 13 MRSA isolates. The extracts from stem bark and root bark showed the most effective antibacterial activity and had no toxicity effects on Vero cells. In another study, $P$. columnaris stem bark demonstrated good antibacterial activity against a wide range of pathogenic bacteria (Siti-Noor-Adnalizawati et al., 2013a). Herein, this study aims to further explore the anti-MRSA activity from several extracts of the stem bark of this plant. We then further isolated and identified the active

\section{*Corresponding author}


compounds of $P$. columnaris. We also evaluate the antiMRSA activity of the active compounds.

\section{MATERIALS AND METHODS}

\section{Collection and preparation of extracts}

The stem bark of $P$. columnaris was collected from Langkawi Island, Kedah, Malaysia and authenticated by a botanist, Mr. Sani Miran. A voucher specimen (WYA 497) was deposited at the Herbarium of Universiti Kebangsaan Malaysia. The outer layer of the stem bark was removed, dried in shaded room and ground to a fine powder using a Waring mill blender. The dried powder (100 g) was soaked in $500 \mathrm{~mL}$ of either methanol or acetone for three days at room temperature. The extracts were then filtered through Whatman No. 3 filter paper and concentrated to dryness using rotary evaporator (Heidolph 2 Laborota 4000, Germany). For aqueous extract, $100 \mathrm{~g}$ of powder was boiled for $2 \mathrm{~h}$ in $500 \mathrm{~mL}$ of water. The extract was then filtered prior to freeze drying. Tannins were removed from both methanol and acetone extracts by precipitating with diethyl ether.

\section{Microorganisms}

Clinically isolated MRSA were obtained from Hospital Serdang, Malaysia (7 isolates) and from Microbiology Laboratory culture collection, School of Biosciences and Biotechnology, Faculty of Science and Technology, Universiti Kebangsaan Malaysia (9 isolates). All MRSA isolates were verified by standard microbiological methods through selection of growth in Mannitol Salt Agar containing $7 \% \mathrm{NaCl}$ with $2 \mathrm{mg} / \mathrm{mL}$ of oxacillin followed by confirmation with tube coagulase test and Antibiotic Sensitivity Test.

\section{Anti-MRSA screening}

Anti-MRSA screening of methanol, acetone and aqueous extracts were done by performing disc diffusion test according to Clinical and Laboratory Standards Institute (2006). Test solution was prepared by diluting $10 \mu \mathrm{L}$ of methanol, acetone, or aqueous extracts at $50 \mathrm{mg} / \mathrm{mL}$ with $5 \%$ methanol in phosphate buffered saline (PBS), 5\% acetone in PBS or sterile distilled water accordingly. Antibiotic discs of vancomycin $30 \mu \mathrm{g}(\mathrm{BBL})$ and rifampicin $5 \mu \mathrm{g}$ (BBL) were used as positive controls for MRSA. Negative controls include $10 \mu \mathrm{L}$ of either $5 \%$ methanol in PBS, $5 \%$ acetone in PBS and sterile distilled water. The plates were then incubated at $37^{\circ} \mathrm{C}$ for $24 \mathrm{~h}$. Anti-MRSA activity was evaluated by measuring the zone of growth inhibition (diameter in $\mathrm{mm}$ ) surrounding each disc. All tests were repeated three times in order to achieve optimal fidelity of results and to obtain the mean and standard deviation (SD).

\section{Determination of MIC and MBC}

Minimum inhibition concentration (MIC) test was done in 96-well sterile microplate according to Mothanka et al. (2010) with slight modification. Two fold serial dilutions of each extracts ranging from 0.78 to $100 \mathrm{mg} / \mathrm{mL}$ were prepared prior to incorporation of $100 \mu \mathrm{L}$ of each diluted extract into respective wells. Sterile Mueller-Hinton Broth $(80 \mu \mathrm{L})$ and $20 \mu \mathrm{L}$ of $10^{7} \mathrm{CFU} / \mathrm{mL}$ MRSA were introduced into all wells. Vancomycin hydrochloride (Sigma) at concentrations ranging from 0.0625 to $4 \mathrm{mg} / \mathrm{mL}$ was included as positive control. The extract-broth mixture serve as turbidity reference, broth only as sterility control and MRSA-broth suspension as inoculums viability controls. The test was done in duplicates. Turbidity of each well was measured after incubation at $35^{\circ} \mathrm{C}$ for $24 \mathrm{~h}$ by using microplate reader (Biorad Model 680) at $595 \mathrm{~nm}$. MIC values were determined by the lowest concentration of the extract that inhibited the microorganisms' growth. For Minimum Bactericidal Concentration (MBC) test, 10 $\mu \mathrm{L}$ of sample from all the clear wells by MIC was streaked onto nutrient agar (NA) plates and incubated at $35^{\circ} \mathrm{C}$ for $24 \mathrm{~h}$. The MBC values were recorded as the lowest concentration showing no growth on the plate.

\section{Thin layer chromatography bioautography}

Thin Layer Chromatography was done to separate compounds available in tannin-free methanol and acetone extracts. For separation of compounds, $2 \mu \mathrm{L}$ tannin-free extract at $50 \mathrm{mg} / \mathrm{mL}$ was applied to silica gel plate (TLC aluminium sheets, $5 \times 5 \mathrm{~cm}$, Silica Gel $60 \mathrm{~F}_{254}$, Merck) and developed using hexane:ethyl acetate (8.5:1.5). The developed TLC plates were kept dried overnight in fume hood. The plates were sterilized under a UV lamp for 30 min and used for TLC bioautography by direct, contact and immersion/agar overlay tests against all sixteen MRSA isolates.

Direct bioautography procedure was done according to Horváth et al. (2002) with some modifications. The plates were dipped in nutrient broth containing $10^{6}$ $\mathrm{CFU} / \mathrm{mL}$ test bacteria. The plates were incubated at $35^{\circ} \mathrm{C}$ for $2 \mathrm{~h}$. The plates were then dipped in $5 \mathrm{mg} / \mathrm{mL}$ of $3-(4,5-$ dimethylthiazol-2-yl)-2,5-diphenyltetrazolium bromide (MTT) and incubated further at $35{ }^{\circ} \mathrm{C}$ for $24 \mathrm{~h}$ in humid condition.

Contact bioautography procedure was done according to Das et al. (2010) with some modifications. TLC plates were placed aseptically onto nutrient agar (NA) and left for $5 \mathrm{~h}$ in order to allow diffusion of fractions in the agar. Fractions were marked at the bottom of agar plate and TLC plates were then removed from the surface of agar with sterile tweezer. MRSA inoculum at $10^{6} \mathrm{CFU} / \mathrm{mL}$ was evenly spread onto the surface of the respective NA using sterile cotton swab and were incubated at $35^{\circ} \mathrm{C}$ for $24 \mathrm{~h}$.

Immersion/agar overlay procedure was done according to Sharma et al. (2009) with some modifications. TLC plates were covered by molten agar containing MRSA and left for $10 \mathrm{~h}$ to allow the fractions to diffuse into the agar. The plates were then incubated at 
$35^{\circ} \mathrm{C}$ for $24 \mathrm{~h}$. After incubation, the plates were sprayed with $5 \mathrm{mg} / \mathrm{mL}$ MTT and further incubated at $35^{\circ} \mathrm{C}$ for 24 $h$. The areas of inhibition were marked and relevant $R_{f}$ values were recorded. All the above tests were run in duplicates.

\section{Isolation and identification of anti-MRSA bioactive compounds}

Bioactive tannin-free methanol and acetone extracts (25 $\mathrm{mg}$ each) were further fractionated by preparative thin layer chromatography (P-TLC; $20 \times 20 \mathrm{~cm}$ glass plates covered with Silica 60, F254; 0.5 mm Merck 7749) using hexane:ethyl acetate $(8.5: 1.5)$. Reference bands for the fractions were determined in parallel on another P-TLC $(10 \times 20 \mathrm{~cm})$ which was detected under UV-light (at $A_{254}$ and $A_{365}$ ). Further detection of bands was done by spraying of TLC plates with cerium (IV) sulphate solution (Bilia et al., 1996; Rodriguez et al., 2008). Active compounds 1 and 2 on the P-TLC were separately removed by scraping off the corresponding bands according to their $R_{f}$ values and washed five times with acetone. Both compounds were subjected to TLC to check for quality and purity. Purified compounds 1 and 2 were analysed using nuclear magnetic resonance (NMR) (JEOL ECM-400) spectral data.

\section{Scanning Electron Microscopy}

MRSA which were treated separately with stigmasterol and lupeol (with their respective MIC value, $12.5 \mathrm{mg} / \mathrm{mL}$ each) and untreated (as control) were inoculated on brain heart infusion agar after $24 \mathrm{~h}$ incubation at $37^{\circ} \mathrm{C}$. After 24 $\mathrm{h}$ incubation at $37{ }^{\circ} \mathrm{C}$, the bacteria culture agar were sliced into $1 \mathrm{~cm}^{3}$ and fixed with $2 \%$ glutaraldehyde for 24 $\mathrm{h}$ at $4{ }^{\circ} \mathrm{C}$. After fixation, samples were washed with $0.1 \mathrm{M}$ phosphate buffer. Subsequently, the samples were dehydrated in graded ethanol, critical-point dried in $\mathrm{CO}_{2}$, mounted onto stubs, coated with gold and observed on a Carl Zeiss LEO 1450VP scanning electron microscope.

\section{Transmission Electron Microscopy}

MRSA with or without addition of stigmasterol or lupeol (with their respective MIC value, $12.5 \mathrm{mg} / \mathrm{mL}$ each) were harvested by centrifugation and washed once with phosphate buffer saline, pH 7.4. MRSA cells were prepared for transmission electron microscopy (TEM) by primary fixation in $2 \%$ glutaraldehyde for at least $24 \mathrm{~h}$ at 4 ${ }^{\circ} \mathrm{C}$ and post-fixation in $1 \%$ osmium tetroxide for $2 \mathrm{~h}$ at room temperature. The samples were dehydrated in graded ethanol, embedded in epoxy resin, polymerizing, sectioning and staining with uranyl acetate followed by Reynolds' stain. The ultrathin sections were viewed and photographed using a Philips CM12 transmission electron microscope.

\section{RESULTS}

Table 1 shows the results in anti-MRSA screening, with MIC and MBC values of extracts against tested MRSA. Aqueous, methanol and acetone extracts from $P$. columnaris stem bark with $50 \mathrm{mg} / \mathrm{mL}$ each showed inhibitory activity against all MRSA with mean of inhibition zones ranged between 9-12, 9-12 and 9-13 mm respectively. Figure 1 is a representative picture for zone of inhibition of $P$. columnaris against selected MRSA.
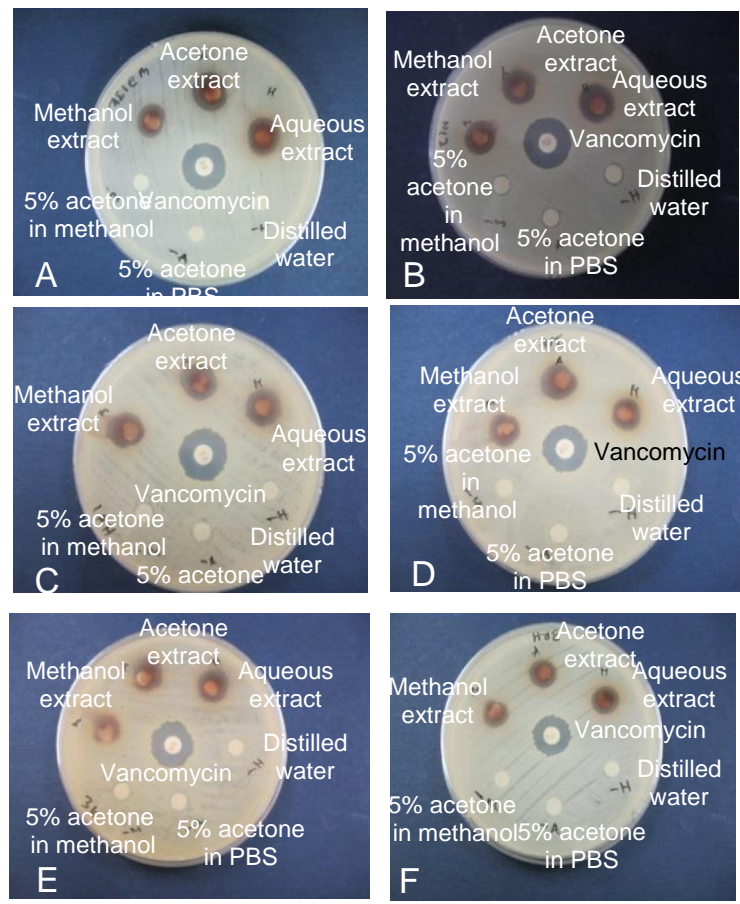

Figure 1: Zone of inhibition of extracts and controls against MRSA 21J (A), MRSA N12 (B), MRSA 1RH (C), MRSA 3AK (D), MRSA 3K (E) and MRSA 3RH (F).

Aqueous extract showed the highest MIC value (50 $\mathrm{mg} / \mathrm{mL}$ ) on most of the MRSA tested. Methanol extract showed lowest MIC concentration of $0.78 \mathrm{mg} / \mathrm{mL}$ against MRSA BM2 and MRSA BM3 and also acetone extract on MRSA N11, MRSA BM2 and MRSA BM3. The lowest $M B C$ value was $1.56 \mathrm{mg} / \mathrm{mL}$ showed by methanol extract on MRSA BM2 and MRSA BM3. Acetone extract also showed the same lowest MBC value on MRSA N11, MRSA BM2 and MRSA BM3. Both methanol and acetone extracts were further investigated due to their profound anti-MRSA activity.

TLC bioautography revealed the presence of two active compounds in both tannin-free methanol and acetone extracts. These compounds were determined to exhibit inhibition areas against all sixteen MRSA tested as indicated by the $R_{f}$ values 0.52 and 0.16 and agreeable in direct and contact bioautography methods but no inhibition in agar overlay. Compounds $1\left(R_{f} 0.52\right)$ and 2 
Mal. J. Microbiol. Vol 10(4) 2014, pp. 225-233

Table 1: Results for anti-MRSA assay of $P$. columnaris stem bark extracts at $50 \mathrm{mg} / \mathrm{mL}$ by disk diffusion test (zones of inhibition in mm), MIC and MBC. The diffusion test was done in triplicates and $\mathrm{MIC} / \mathrm{MBC}$ in duplicates.

\begin{tabular}{|c|c|c|c|c|c|c|c|c|c|c|c|}
\hline \multirow[b]{2}{*}{ MRSA } & \multicolumn{2}{|c|}{$\begin{array}{l}\text { Inhibition zone }(\mathrm{mm}) \text { of } \\
\text { control antibiotics }\end{array}$} & \multicolumn{3}{|c|}{ Methanol extract } & \multicolumn{3}{|c|}{ Acetone Extract } & \multicolumn{3}{|c|}{ Aqueous extract } \\
\hline & Vancomycin & Rifampicin & $\begin{array}{c}\text { Inhibition } \\
\text { zone } \\
(\mathrm{mm}) \\
\end{array}$ & $\begin{array}{c}\mathrm{MIC} \\
(\mathrm{mg} / \mathrm{mL})\end{array}$ & $\begin{array}{c}\mathrm{MBC} \\
(\mathrm{mg} / \mathrm{mL}) \\
\end{array}$ & $\begin{array}{c}\text { Inhibition } \\
\text { zone } \\
(\mathrm{mm}) \\
\end{array}$ & $\begin{array}{c}\mathrm{MIC} \\
(\mathrm{mg} / \mathrm{mL})\end{array}$ & $\begin{array}{c}\mathrm{MBC} \\
(\mathrm{mg} / \mathrm{mL}) \\
\end{array}$ & $\begin{array}{c}\text { Inhibition } \\
\text { zone } \\
(\mathrm{mm}) \\
\end{array}$ & $\begin{array}{c}\mathrm{MIC} \\
(\mathrm{mg} / \mathrm{mL}) \\
\end{array}$ & $\begin{array}{c}\mathrm{MBC} \\
(\mathrm{mg} / \mathrm{mL})\end{array}$ \\
\hline MRSA N11 & $18 \pm 1.00$ & $6 \pm 0.00$ & $10 \pm 1.53$ & 1.56 & 3.12 & $12 \pm 0.58$ & 0.78 & 1.56 & $11 \pm 0.58$ & 50.00 & $>50.00$ \\
\hline MRSA N12 & $17 \pm 0.58$ & $30 \pm 0.00$ & $11 \pm 0.58$ & 12.50 & 12.50 & $13 \pm 1.15$ & 12.50 & 12.50 & $12 \pm 0.58$ & 50.00 & $>50.00$ \\
\hline MRSA N17 & $16 \pm 0.00$ & $26.67 \pm 1.53$ & $9 \pm 1.15$ & 12.50 & 25.00 & $11 \pm 1.15$ & 12.50 & 12.50 & $11 \pm 0.58$ & 50.00 & $>50.00$ \\
\hline MRSA 1RH & $17 \pm 0.58$ & $31 \pm 1.00$ & $11 \pm 0.58$ & 12.50 & 12.50 & $12 \pm 0.58$ & 12.50 & 12.50 & $12 \pm 0.00$ & 50.00 & $>50.00$ \\
\hline MRSA 3AK & $16 \pm 0.58$ & $30 \pm 0.00$ & $10 \pm 0.58$ & 12.50 & 12.50 & $12 \pm 0.58$ & 12.50 & 12.50 & $10 \pm 1.15$ & 50.00 & 50.00 \\
\hline MRSA 3K & $16 \pm 0.00$ & $31.67 \pm 1.53$ & $11 \pm 0.00$ & 12.50 & 12.50 & $12 \pm 0.58$ & 12.50 & 12.50 & $11 \pm 1.53$ & 50.00 & 50.00 \\
\hline MRSA 3RH & $15 \pm 0.58$ & $25.67 \pm 1.15$ & $11 \pm 0.58$ & 12.50 & 12.50 & $11 \pm 0.58$ & 12.50 & 12.50 & $11 \pm 0.00$ & 50.00 & 50.00 \\
\hline MRSA 4J & $16 \pm 0.58$ & $25.67 \pm 1.15$ & $9 \pm 1.15$ & 12.50 & 12.50 & $12 \pm 0.00$ & 12.50 & 12.50 & $11 \pm 0.58$ & 50.00 & $>50.00$ \\
\hline MRSA 21J & $16 \pm 0.00$ & $30 \pm 0.00$ & $11 \pm 0.58$ & 12.50 & 12.50 & $12 \pm 0.58$ & 12.50 & 12.50 & $12 \pm 0.58$ & 50.00 & $>50.00$ \\
\hline MRSA TM & $17 \pm 1.00$ & $31.33 \pm 0.58$ & $9 \pm 1.15$ & 12.5 & 25.00 & $12 \pm 0.58$ & 12.50 & 25.00 & $12 \pm 0.58$ & 50.00 & $>50.00$ \\
\hline MRSA WM1 & $6 \pm 0.00$ & $35 \pm 0.00$ & $10 \pm 1.53$ & 3.12 & 6.25 & $10 \pm 1.15$ & 6.25 & 12.5 & $9 \pm 1.15$ & 50.00 & $>50.00$ \\
\hline MRSA WM2 & $17 \pm 0.58$ & $35.33 \pm 0.58$ & $12 \pm 0.58$ & 3.12 & 6.25 & $10 \pm 1.15$ & 3.12 & 6.25 & $9 \pm 0.00$ & 12.50 & 50.00 \\
\hline MRSA WM3 & $17 \pm 0.58$ & $32.33 \pm 0.58$ & $10 \pm 1.53$ & 6.25 & 12.5 & $10 \pm 1.15$ & 6.25 & 12.5 & $10 \pm 1.15$ & 25.00 & 50.00 \\
\hline MRSA BM1 & $17 \pm 1.15$ & $31.33 \pm 1.15$ & $10 \pm 1.15$ & 6.25 & 12.5 & $9 \pm 1.15$ & 12.50 & 25.00 & $12 \pm 0.00$ & 50.00 & $>50.00$ \\
\hline MRSA BM2 & $17 \pm 0.00$ & $33.67 \pm 0.58$ & $\begin{array}{l}10 \pm 1.53 \\
9.67 \pm 1.5\end{array}$ & 0.78 & 1.56 & $10 \pm 1.53$ & 0.78 & 1.56 & $12 \pm 0.58$ & 25.00 & 50.00 \\
\hline $\begin{array}{l}\text { MRSA BM3 } \\
\text { MRSA } \\
\text { ATCC }\end{array}$ & $6 \pm 0.00$ & $30 \pm 0.00$ & 3 & 0.78 & 1.56 & $9 \pm 1.15$ & 0.78 & 1.56 & $12 \pm 0.58$ & 50.00 & $>50.00$ \\
\hline 43300 & $x$ & $31 \pm 0.00$ & $10 \pm 0.00$ & 12.50 & 25.00 & $9 \pm 1.15$ & 12.50 & 25.00 & $10 \pm 0.00$ & 50.00 & $>50.00$ \\
\hline
\end{tabular}

$x:$ Not tested 


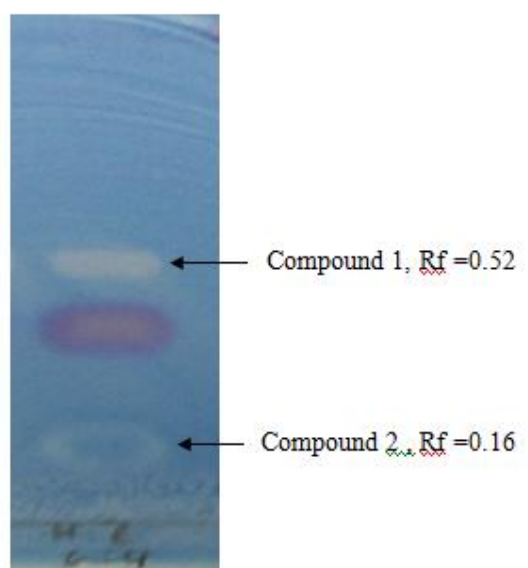

Figure 2: Representative picture of direct TLC bioautography for determination of anti-MRSA activity of compounds 1 and 2 available in tannin-free $P$. columnaris stem bark acetone extract.

$\left(R_{f} 0.16\right)$ exhibited zones of inhibition on all MRSA tested. Figure 2 is a representative picture for direct TLC bioautography against MRSA.

Compounds 1 and 2 which were active on all MRSA tested were further isolated using P-TLC and analysed by NMR spectroscopy. Structural determination of the compounds by NMR enabled us to identify the two triterpenes. The molecular formulas of compounds 1 and 2 were determined as $\mathrm{C}_{30} \mathrm{H}_{50} \mathrm{O}$ and $\mathrm{C}_{29} \mathrm{H}_{48} \mathrm{O}$ respectively.

Compound 1: Amorphous white powder (Figure 3A). ${ }^{1} \mathrm{H}$ NMR (Acetone- $\left.\mathrm{d}_{6}, 400 \mathrm{MHz}\right): \delta 3.13\left({ }^{1} \mathrm{H}, \mathrm{dd}, \mathrm{H}-3\right), \delta$ $2.45\left({ }^{1} \mathrm{H}, \mathrm{m}, \mathrm{H}-19\right), \quad \delta 4.70\left({ }^{1} \mathrm{H}, \mathrm{s}, \mathrm{H}-29 \mathrm{a}\right), \delta 4.55\left({ }^{1} \mathrm{H}, \mathrm{s}\right.$, $\mathrm{H}-29 \mathrm{~b}) .{ }^{13} \mathrm{C}$ NMR (Acetone- $\left.\mathrm{d}_{6}, 400 \mathrm{MHz}\right): \delta 78.4$ (C-3), 151.8 (C-20), 109.9 (C-29).

Compound 2: White colourless needles (Figure 3B). ${ }^{1} \mathrm{H}$ NMR (Acetone- $\left.\mathrm{d}_{6}, 400 \mathrm{MHz}\right): \delta 3.40\left({ }^{1} \mathrm{H}, \mathrm{m}, \mathrm{H}-3\right)$, $5.32\left({ }^{1} \mathrm{H}, \mathrm{d}, \mathrm{H}-6\right), 5.20\left({ }^{1} \mathrm{H}, \mathrm{dd}, \mathrm{H}-22\right), 5.08\left({ }^{1} \mathrm{H}, \mathrm{dd}, \mathrm{H}-23\right)$. ${ }^{13} \mathrm{C}$ NMR (Acetone- $\left.\mathrm{d}_{6}, 400 \mathrm{MHz}\right): \delta 142.4(\mathrm{C}-5), 139.4$ (C22), 130.2 (C-23), 121.6 (C-6), 71.8 (C-3).

Compound 1 has been identified as $(3 \beta, 13 \xi)$-lup20(29)-en-3-ol, clerodol, monogynol B, Fagarasterol, Farganasterol or lupeol (Figure 4A) and compound 2 as stigmasterin or stigmasterol (Figure $4 \mathrm{~B}$ ).
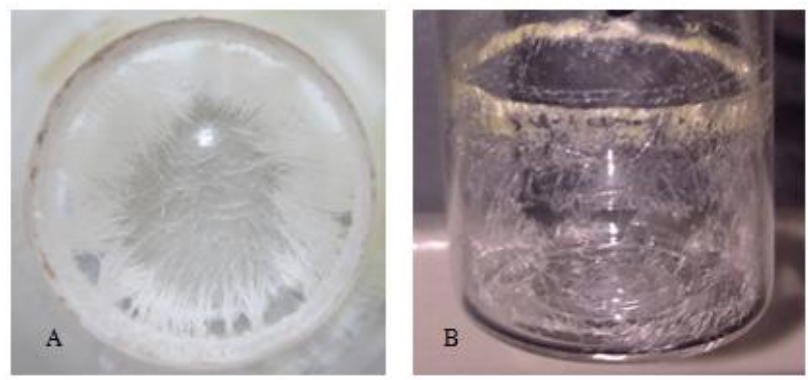

Figure 3: Physical forms of $A$, lupeol as amorphous white powder and B, stigmasterol as white colourless needles.
A
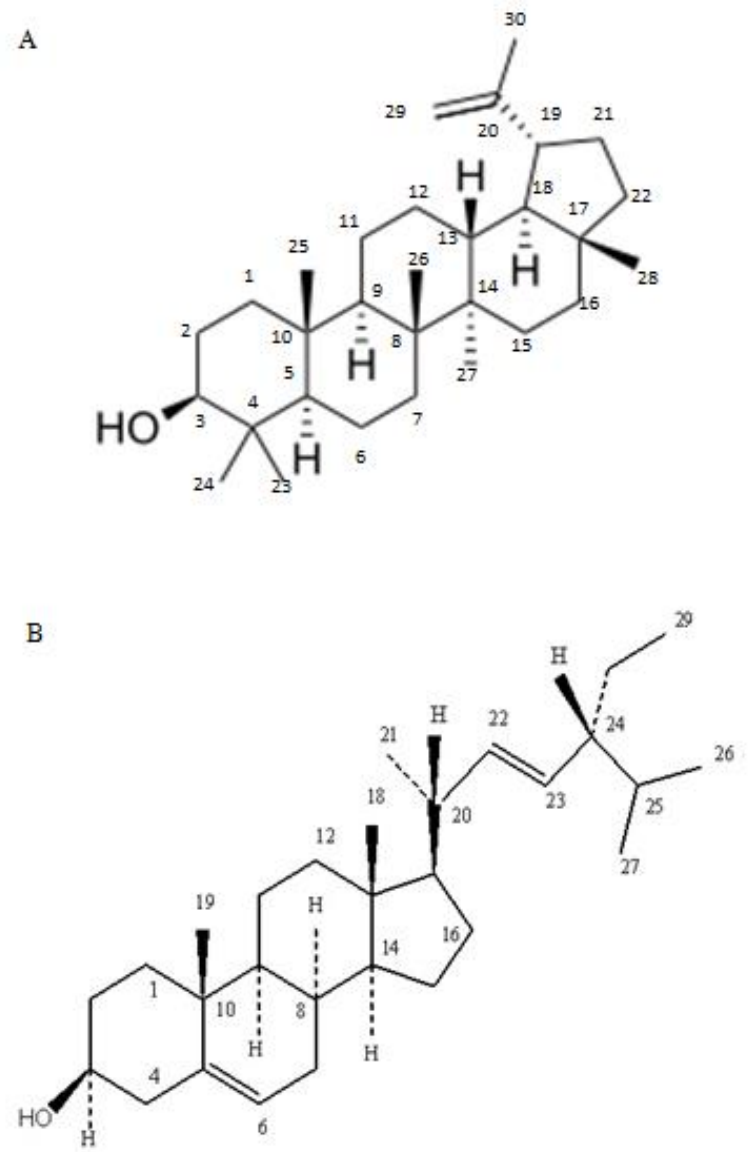

Figure 4: Chemical structure of A, lupeol and B, stigmasterol.

Scanning and transmission electron microscopy were performed for untreated and treated MRSA to determine morphological and ultra-structural changes caused by both stigmasterol and lupeol at their minimum inhibitory concentration (12.5 mg/mL) after $24 \mathrm{~h}$ (Figure 5). In scanning electron microscopy, untreated MRSA appeared to have a regular, smooth surface and spherical in grapelike clusters (Figure 5A). For MRSA treated with minimum inhibitory concentration of stigmasterol (Figure 5B) and lupeol (Figure $5 \mathrm{C}$ ) at $12.5 \mathrm{mg} / \mathrm{mL}$ each, two types of cells were observed after $24 \mathrm{~h}$ of incubation: MRSA treated with stigmasterol showed agglomerated cells and only minor morphological alterations but MRSA treated with lupeol showed many distorted cells. These morphological features in MRSA cells may be due to the action on the cell wall followed by loss of cell volume. These findings were confirmed by transmission electron microscopy. Untreated MRSA possessed structural integrity which was confirmed by having thicker cell wall (Figure $6 \mathrm{~A}$ and $\mathrm{B}$ ). MRSA treated with either stigmasterol or lupeol showed disruption and damage to the cell wall, resulting in a release of cytoplasmic contents (Figure $6 \mathrm{C}$ and $\mathrm{F}$ ), loss of cell walls (Figure $6 \mathrm{E}, \mathrm{G}$ and $\mathrm{H}$ ), alterations in morphology (Figure $6 D$ and $E$ ) and decrease in cell volume (Figure $6 \mathrm{C}, \mathrm{D}, \mathrm{F}$ and $\mathrm{G}$ ). 

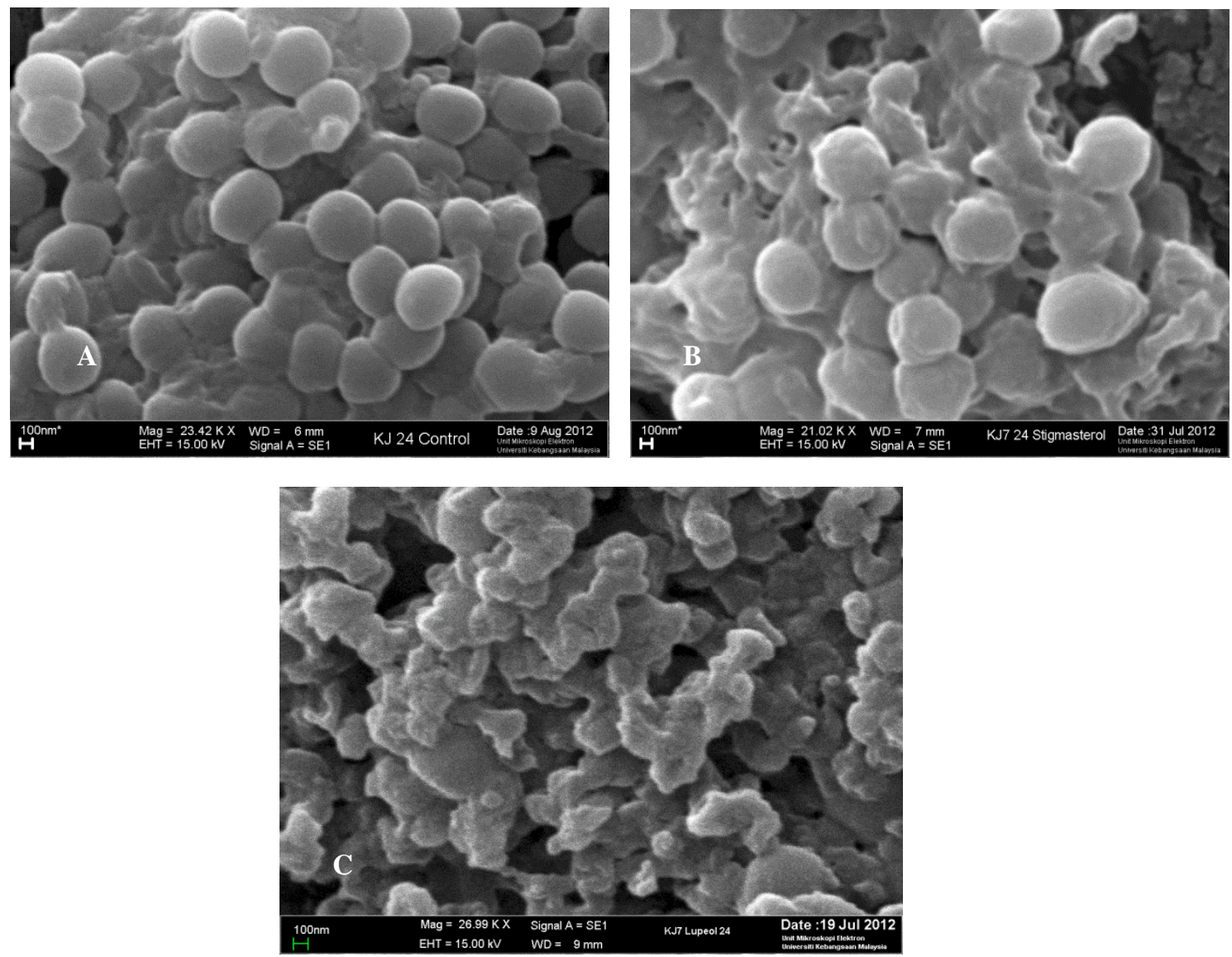

Figure 5: Scanning electron microscopy of MRSA treated with stigmasterol and lupeol obtained from $P$. columnaris for $24 \mathrm{~h}$ at $37^{\circ} \mathrm{C}$. A, control; B, stigmasterol at $12.5 \mathrm{mg} / \mathrm{mL}$ and $\mathrm{C}$, lupeol at $12.5 \mathrm{mg} / \mathrm{mL}$. Bars $=0.1 \mu \mathrm{m}$.

\section{DISCUSSION}

$P$. columnaris stem bark extracts showed anti-MRSA effects as indicated by disk diffusion assay, MIC and MBC tests in this study. Even though the disk diffusion test result did not show differences in the mean of the inhibition zone diameter between the three extracts, the results of MIC and MBC showed contradictory results with aqueous extract disk diffusion test. This contradiction could be due to the ability of polar active compounds in aqueous extract to diffuse further on the agar and displayed inhibition zone compared to less polar active compounds in methanol and acetone extracts which were more active but can only show inhibition zone within limited diameter due to the lesser ability to diffuse (Pauli et al, 2005). By performing MIC and MBC tests, the agar barrier factor that influenced the disk diffusion test was eliminated and the active compounds can directly be exposed to the tested MRSA.

Direct and contact TLC bioautography showed that both tannin-free acetone and methanol extracts have two similar active compounds that were responsible to inhibit all the MRSA isolates in the study. The observation of antibacterial and anti-yeast activities from tannin-free methanol extracts from the same part of the plant was also reported in Siti-Noor-Adnalizawati et al. (2013a). Agar overlay method failed to indicate any inhibition by these two active compounds thus concluded as insensitive procedure in TLC bioautography. In a previous study by Brantner (1997) the effect of varying different parameters in antibacterial assays showed that more precise results were obtained when the bacteria were suspended in the nutrient medium which was poured over the TLC plates than when they were distributed over the solidified nutrient medium which was already on the plates. Variation of the culture medium and stains also gave different results, with para-iodonitrotetrazolium violet (INT) proved to be the most suitable detection reagent. However, there is also limitation to direct bioautography method which is only applicable to microorganisms that can grow directly on the TLC plate (Marston, 2011). In this study, we can conclude that direct bioautography method is more sensitive and suitable for the screening of anti-MRSA new compounds.

Compounds 1 and 2 which were active towards all MRSA isolates tested were identified as lupeol and 

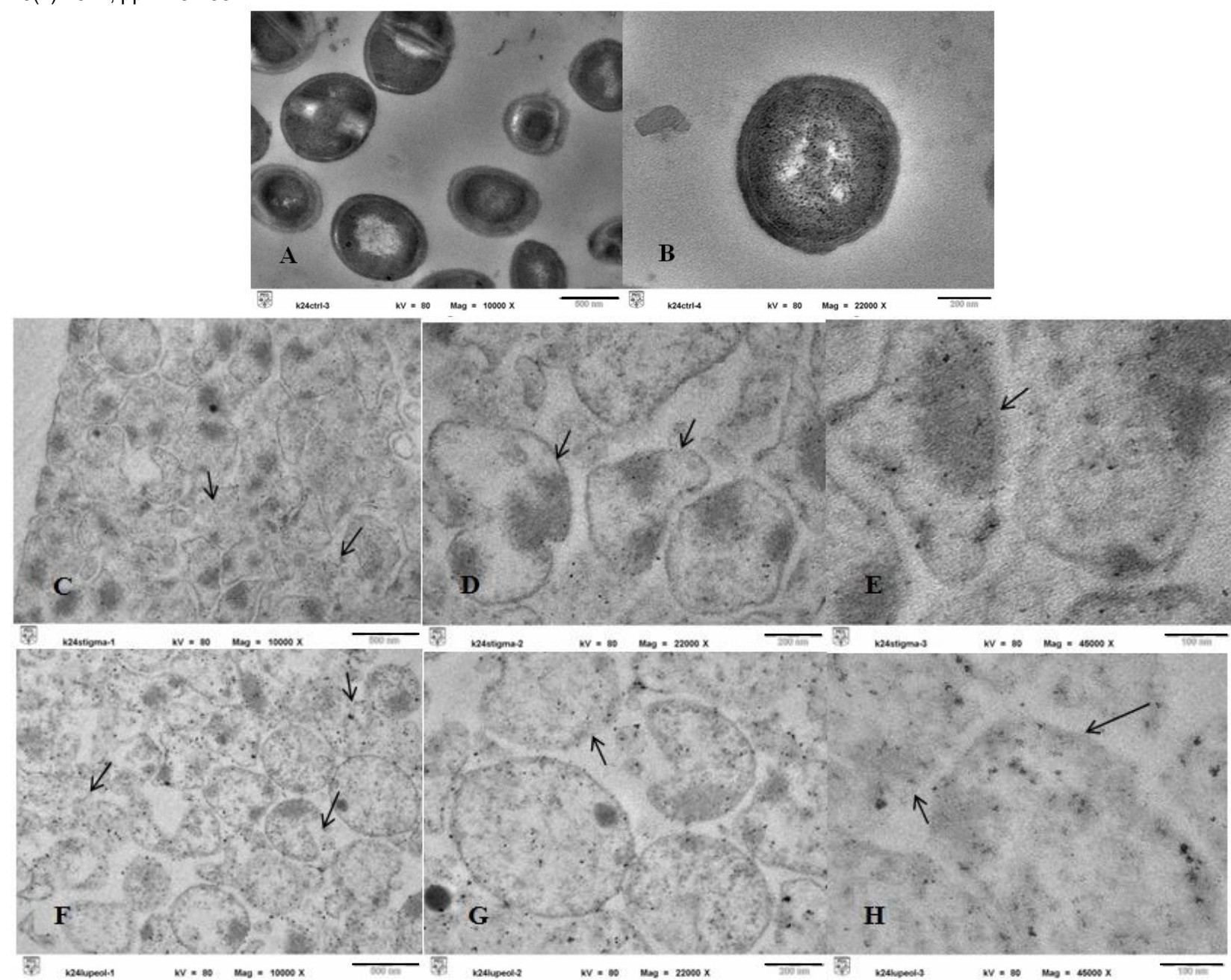

Figure 6: Transmission electron microscopy of MRSA treated with stigmasterol and lupeol obtained from $P$. columnaris for $24 \mathrm{~h}$ at $37^{\circ} \mathrm{C}$. A and $\mathrm{B}$, control; $\mathrm{C}, \mathrm{D}$ and $\mathrm{E}$, stigmasterol at $12.5 \mathrm{mg} / \mathrm{mL} ; \mathrm{F}, \mathrm{G}$ and $\mathrm{H}$, lupeol at $12.5 \mathrm{mg} / \mathrm{mL}$. Bars $\mathrm{A}, \mathrm{C}$ and $\mathrm{F}=0.5 \mu \mathrm{m} ; \mathrm{B}, \mathrm{D}$ and $\mathrm{G}=0.2 \mu \mathrm{m} ; \mathrm{E}$ and $\mathrm{H}=0.1 \mu \mathrm{m}$. Arrows in $\mathrm{C}$ and $F$ indicates release of cytoplasmic contents; $E$, $G$ and $H$-loss of cell walls 
stigmasterol by NMR spectral data. Both compounds were also isolated by Jamal et al. (2009b) in ethyl acetate extract of root bark of the same plant. They also succeeded in isolating stigmasterol which is a triterpene and two more triterpenes which were also identified as taraxerone and taraxerol from the methanol extract of $P$. columnaris root bark (Jamal et al., 2009a). Several studies on antibacterial activities of extracts containing lupeol and stigmasterol showed weak to moderate antimicrobial activity (Gallo and Sarachine, 2009; Parvin et al., 2009; Sultana et al., 2009). However, a study done by Suryati et al. (2011) showed contrary result with MIC values of lupeol against $E$. coli, B. subtilis and $S$. aureus were 150, 220 and $130 \mu \mathrm{g} / \mathrm{mL}$ respectively. These contradicting results in the antibacterial activity of lupeol has led to the hypothesis that different activities of this compound might be due to the ability of some bacteria to biotransform the substances yielding different metabolites that possess different activities (Eiznhamer and $\mathrm{Xu}$, 2004).

Morphological and ultra-structure alterations of the MRSA treated with stigmasterol and lupeol after $24 \mathrm{~h}$ were revealed by scanning and transmission electron microscopy. Both compounds affect the cell wall and lead to cell wall disruption, release of cytoplasmic contents and decreased in cellular volume. Observations on crude methanolic $P$. columnaris which contain both these compounds have shown not only similar results but also causes disorganisation of cell division (Siti-NoorAdnalizawati et al., 2013b).

\section{CONCLUSIONS}

In conclusion, it is suggested that both lupeol and stigmasterol can be new source for new anti-MRSA agents with further research to be undertaken. Furthermore, the structure of both compounds differs from the currently used antibiotics. Thus, the emergence of cross-resistance is unlikely to be caused either and development of resistance to these compounds will be delayed. Studies are underway to investigate the mechanism of action of both compounds on MRSA. Future investigation will also involve in vitro and in vivo toxicity studies to elucidate cytotoxic effect of both compounds.

\section{ACKNOWLEDGEMENTS}

Financial supports from Universiti Kebangsaan Malaysia (UKM-GUP-2011-264; BKBP K006401), Ministry of Health Malaysia (NMMR-11-59-8309) and Ministry of Higher Education Malaysia (UKM-ST-FRGS0039-2006; UKM-ST-FRGS0110-2009) are duly acknowledged.

\section{REFERENCES}

Bilia, A. R., Ciampi, L., Méndez, J. and Morelli, I. (1996). Phytochemical investigations of Licania genus. Flavonoids from Licania pyrifolia. Pharmaceutica Acta Helvetiae 71, 199-204.
Brantner, A. H. (1997). Influence of various parameters on the evaluation of antibacterial compounds by the bioautographic TLC assay. Pharmaceutical and Pharmacological Letters 7, 152-154.

Clinical and Laboratory Standards Institute. (2006). Performance standards for antimicrobial disk susceptibility test: Approved standard. 9th edn. CLSI, Wayne, PA, USA.

Das, K., Tiwari, R. K. S., and Shrivastava, D. K. (2010). Techniques for evaluation of medicinal plant products as antimicrobial agents: Current methods and future trends. Journal of Medicinal Plants Research 4(2), 104-111.

Delaney, J. A. C., Schneider-Lindner, V., Brassard, P. and Suissa, S. (2008). Mortality after infection with methicillin-resistant Staphylococcus aureus (MRSA) diagnosed in the community. BMC Medical Education 6, 2. (1-8).

Eiznhamer, D. A. and Xu, Z. Q. (2004). Betulinic acid: A promising anticancer candidate. IDrugs 7(4), 359-373.

Falcone, M., Serra, P. and Venditti, M. (2009). Review article: Serious infections due to methicillin-resistant Staphylococcus aureus: An evolving challenge for physicians. European Journal of Internal Medicine 20, 343-347.

Fazari, G. M., Azilawaty, A., Nazlina, I. and Yaacob, W. A. (2011). Cytotoxic effect and anti-MRSA activity of methanolic extracts of Phyllanthus gracilipes and Phyllanthus columnaris. Sains Malaysiana 40(5), 457466.

Gallo, M. B. C. and Sarachine, M. J. ( 2009). Biological activities of lupeol. International Journal of Biomedical and Pharmaceutical Sciences 29, 46-66.

Gastmeier, P. (2010). Healthcare associated versus community-acquired infections: A new challenge for science and society. International Journal of Medical Microbiology 300, 342-345.

Hiramatsu, K., Okuma, K., Ma, X. X., Hori, S. and Kapi, M. (2002). New trends in Staphylococcus aureus infections: Glycopeptides resistance in hospital and methicillin resistance in the community. Current Opinion in Infectious Diseases 15, 407-413.

Horváth, G., Kocsis, B., Botz, L., Németh, J., Szabó, L. G. (2002). Antibacterial activity of Thymus phenols by direct bioautography. Acta Biologica Szegediensis 46(3-4), 145-146.

Jamal, A. K., Yaacob, W. A. and Din, L. B. (2009a). Triterpenes from the root bark of Phyllanthus columnaris. Australian Journal of Basic and Applied Sciences 3(2), 1428-1431.

Jamal, A. K., Yaacob, W. A. and Din, L. B. (2009b). A chemical study on Phyllanthus columnaris. European Journal of Scientific Research 28(1), 76-81.

Kerttula, A-M., Lyytikäinen, O., Kardén-Lilja, M., Ibrahem, S., Salmenlinna, S. and Virolainen, A. (2007). Nationwide trends in molecular epidemiology of methicillin resistant Staphylococcus aureus, Finland, 1997-2004. BMC Infectious Diseases 7, 94 (1-9).

Madani, T. A. (2002). Epidemiology and clinical features of methicillin-resistant Staphylococcus aureus in the 
university hospital, Jeddah, Saudi Arabia. The Canadian Journal of Infectious Diseases 13(4), 245250.

Marston, A. (2011). Thin-layer chromatography with biological detection in phytochemistry. Journal of Chromatography A 1218, 2676-2683.

Motlhanka, D., Houghton, P., Miljkovic-Brake, A. and Habtemariam, S. (2010). A novel pentacyclic triterpene glycoside from a resin of Commiphora glandulosa from Botswana. African Journal of Pharmacy and Pharmacology 4(8), 549-554.

Neoh, H-M., Hori, S., Komatsu, M., Oguri, T., Takeuchi, F. and Cui, L. (2007). Impact of reduced vancomycin susceptibility on the therapeutic outcome of MRSA bloodstream infections. Annals of Clinical Microbiology and Antimicrobials 6, 13 (1-6).

Parvin, M. N., Rahman, M. S., Islam, M. S. and Rashid, M. A. (2009). Chemical and biological investigations of Dillenia indica Linn. Bangladesh Journal of Pharmacology 4, 122-125.

Pauli, G. F., Case, R. J., Inui, T., Wang, Y., Cho, S., Fischer, N. H. and Franzblau, S. G. (2005). New perspectives on natural products in TB drug research. Life Science 78(5), 485-494.

Rodríguez, M., Hasegawa, M., González-Mújica, F., Motta, N., Castillo, A., Jimmy Castillo, J., Zea, E., Mora, K., Sousa, L., González, A. and Camejo, D. (2008). Antidiabetic and antiradical activities of plants from Venezuelan Amazon. Brazilian Journal of Pharmacognosy 18(3), 331-338.

Sultana, S., Rahman, M. S., Hossain, M. A., Hossain, M. K. and Rashid, M. A. (2009). Phytochemical and biological investigations of Ixora lutea Hutch. Dhaka University Journal of Pharmaceutical Sciences 8(1), 17-21.

Sharma, A., Patel, V. K. and Ramteke, P. (2009). Identification of vibriocidal compounds from medicinal plants using chromatographic fingerprinting. World Journal of Microbiology and Biotechnology 25, 19-25.

Siti-Noor-Adnalizawati, A., Angeline, S., Nazlina, I. and Yaacob, W. A. (2013a). Antimicrobial activity of Phyllanthus columnaris stem bark extract. Malaysian Applied Biology 42(1), 83-87.

Siti-Noor-Adnalizawati, Nazlina, I. and Yaacob, W. A. (2013b). Disorganization of cell division of methicillinresistant Staphylococcus aureus by methanolic extract from Phyllanthus columnaris stem bark. AIP Conference Proceedings 1571, 222-226.

Suryati, S., Nurdin, H., Dachriyanus, D. and Hj Lajis, M. N. (2011). Structure elucidation of antibacterial compound from Ficus deltoidea Jack Leaves. Indonesian Journal of Chemistry 11(1), 67-70.

Vaudaux, P., Francois, P., Berger-Bächi, B. and Lew, D. P. (2001). In vivo emergence of subpopulations expressing teicoplanin or vancomycin resistance phenotypes in a glycopeptide-susceptible, methicillin resistant strain of Staphylococcus aureus. Journal of Antimicrobial Chemotheraphy 4, 163-170.

Weigel, L. M., Donlan, R. M., Shin, D. H., Jensen, B., Clark, N. C. and McDougal, L. K. (2007). High level vancomycin-resistant Staphylococcus aureus isolates associated with a polymicrobial biofilm. Antimicrobial Agents and Chemotheraphy 51, 231-238.

Witte, W. (1999). Antibiotic resistance in Gram-positive bacteria: Epidemiological aspects. Journal of Antimicrobial Chemotherapy 44, 1-9. 